REVIEW ARTiCLe

\title{
Sod production in Brazil
}

\author{
Roberto Lyra Villas Bôas ${ }^{1}$ ㅇ; ; Leandro José Grava de Godoy ${ }^{2 *}$ (1); Clarice Backes ${ }^{3}$ (D); \\ Alessandro José Marques dos $\operatorname{Santos}^{3}$ (i); Livia Sancinetti Carribeiro ${ }^{4}$ (i) \\ ${ }^{1}$ Universidade Estadual Paulista (Unesp), Faculdade de Ciências Agronômicas, Botucatu-SP, Brazil. \\ ${ }^{2}$ Universidade Estadual Paulista (Unesp), Câmpus de Registro, Registro-SP, Brazil. \\ ${ }^{3}$ Universidade Estadual de Goiás (UEG), Departamento de Zootecnia, São Luís dos Montes Belos-GO, Brazil. \\ ${ }^{4}$ Associação Nacional Grama Legal, Piracicaba-SP, Brazil.
}

\begin{abstract}
The history of sod production in Brazil is somewhat recent when compared with conventional agricultural crops. This review describes the beginning of sod production in Brazil and the introduction of Emerald grass, as well as the emergence of Sod Growers Associations, which coincides with the marked expansion of the sector. The grass species and cultivars grown in Brazil are also presented and the main characteristics described. The text also reports few data in sod production area in the country, providing an overview planting evolution and characteristics of the market.
\end{abstract}

Keywords: turf, turfgrass, zoysiagrass, bermudagrass, carpetgrass.

\section{Resumo}

\section{A produção de gramas no Brasil}

A história da grama cultivada no Brasil é algo recente se comparado às culturas agrícolas convencionais. Nesta revisão são descritos o início da produção de grama no Brasil e a introdução da grama Esmeralda, bem como o surgimento das Associações de Produtores de Grama que coincide com a forte expansão do setor. São apresentados também espécies e cultivares de gramas cultivadas no Brasil, sendo descritas as suas principais características. O texto relata também os poucos levantamentos de área de produção de grama no país, sendo possível avaliar a evolução do plantio e as características do mercado.

Palavras-chave: grama, gramado, grama Zoysia, grama Bermuda, grama São Carlos.

\section{History of sod production in Brazil}

Turfgrass transplanting in Brazil was originated through the extractive practices, with grasses growing in grasslands and being cut into slabs with a hoe. Paspalum notatum Flüggé, known as batatais or gramão grass, was found on many farms, extracted and sold informally, with no specific production units (Arigoni, 2012; Souza et al., 2020).

The first possible record to be considered the onset of cultivated sod production in Brazil occurred in the municipality of Curitiba, State of Paraná, in 1966. The family of Mr. Pedro Luis Scroccaro established a pasture for dairy cattle with the grass Axonopus affinis Chase called sempre-verde or Argentina grass, as they believed it originated from that country (Scroccaro ${ }^{1}$ ).

Mr. Silverio Bonato, a gardener from Curitiba, had bought the turf to be planted it in residential gardens offering a very high price, which caused distrust of the producer, who then refused to make the sale. Sometime later, the gardener returned to the farm and convinced $\mathrm{Mr}$. Scroccaro to sell a "load" of the turf. Since then, following the growth of Curitiba, the sale of turf intensified and, in the early 1970s, the Scroccaro family expanded the planted area (Schvabe, 2011).

The Gabardo family, one of the largest producers and a pioneer in sod production in Paraná started this activity

${ }^{1}$ Scroccaro, P. L. (Farmer, Curitiba-PR, Brazil) Personal communication, 2020.

*Corresponding author: leandro.godoy@unesp.br 
in 1969, in São José dos Pinhais, and its first productions were sold to the Scroccaro family, as the latter were unable to meet all the demand using their land (Grameira Gabardo, 2020).

In 1975, the Scroccaro family developed the first sod harvest machine, although rudimentary, was efficient in that it saved a lot of manual labor for harvest sod ( Scroccaro $\left.^{2}\right)$.

The sod production in São Paulo State started in 1971, in the city of Itapetininga, when the agronomist Minoru Ito and his business partner Rene Arruda (owned a gardening company and already sold batatais grass sods) acquired two sods of Zoysia pacifica (Goudswaard) M. Hotta \& S. Kuroki (known as japonesa grass) at Ceasa, which was used to multiply the turf. With the increase in planted area, Minoru Ito acquired an imported sod harvest machine and started selling japonesa grass as sods in 1973 (Zanon and Pires, 2010). In 1974, he brought seedlings of the sempreverde grass from Ponta Grossa, state of Paraná, when the production of this species started in the state of São Paulo. Due to the existence of a native grass with broad leaves and characteristics similar to those of sempre-verde grass at the dam in São Paulo, Minoru and Rene called this new species as São Carlos grass to avoid confusion with the existing turf production $\left(\mathrm{Arruda}^{3}\right.$ ).

Following the successful introduction of São Carlos grass in the state of São Paulo and the intensification of sales, the Itograss ${ }^{\mathrm{TM}}$ company was officially formed in 1975 (Itograss, 2020a). Currently, the company has 30 sod production farms in 13 states of Brazil and the Federal District and markets eight grass cultivars, which are: cv. Emerald, cv. Imperial Emerald, cv. São Carlos Plus, cv. Bermuda Tifway 419, cv. Bermuda Tifdwarf, cv. Bermuda Celebration, cv. Zeon Zoysia and cv. Geo Zoysia. In 1977, Rene and Minoru brought some rhizomes of Asian origin from the University of California (Riverside) This material had promising characteristics for Brazil, as it is a turf with thin, soft leaves and very attractive colors. Due to its emerald-green color and the existence of a species in the USA called 'Emerald', the two named this turf 'Esmeralda' ${ }^{\mathrm{TM}}$ '. The first sod sales took place after three years of establishment in Brazil (Ito ${ }^{4}$ ). It is important to mention that cv. Emerald, released in the USA in 1955 (Patton et al., 2017), is a cross between Zoysia japonica and Zoysia pacifica, whereas cv. 'Esmeralda ${ }^{\mathrm{TM}}$ ', produced in Brazil, is Zoysia japonica.

From the sale of sod, several other producers started selling 'Esmeralda', which spread throughout the region of Itapetininga, which eventually became one of the main producing regions in the country.

In 2002, the company Green Grass TM, founded in 1990, in Viamão, RS, established the first area of sod production, in Brazil, with International Certification of genetic purity, in the Rio Grande do Sul. Today, the company has more than 1,000 hectares of sod production, distributed across the states of Rio Grande do Sul, São Paulo, and Rio de Janeiro $\left(\right.$ Matte $\left.^{5}\right)$.

\section{Brazilian Sod Growers Association}

Due to the expansion of sod in Brazil, producers began to found associations aiming to strengthen the entire production chain. The first association to be formed was the Sod Growers Association of Paraná State, AGRAPAR, created on February 24, 2003. Inspired by AGRAPAR, the Sod Growers Association of São Paulo State, AGRAESP, was founded on June 7, 2003. Since the beginning, a close relationship was created between the two associations, which always sought to work together for the benefit and development of the sector.

Over time, with the development of sod production in Brazil, AGRAESP and its associates decided it was time to grow and collaborate with all sod growers in the country. Thus, AGRAESP became AGRABRAS, the Brazilian Sod Growers Association, and AGRAPAR had already ended its activities in 2006.

In 2010, the "Grama Legal" Project was created within AGRABRAS with the objective of to stimulate sod sales with guarantee of origin (Arigoni, 2012; Infograma, 2015). The project was sanctioned by the public administration, in all public tenders, based on the application of Law no. 10,711 of 2003 and Decree no. 5,123 of 2004, which created the National Registry for Seeds and Seedlings RENASEM (BRASIL, 2003; 2004).

In 2012, the "Grama Legal" Project became the "Grama Legal" National Association. At present, the two associations represent the country's sod producers, and their central goal is to defend the interests of the sod production sector at the national level (Associação Nacional Grama Legal, 2020).

The first item of action of the "Grama Legal" Project was the regularization of pesticides used in sod production, with the inclusion of sod as a subtype of the "pasture" crop, incorporating all its biological targets and the regularization and alteration of Normative Instruction (NI) number $36 / 2009$ by NI $15 / 2016$. This facilitated the process for extending the use of pesticides to ornamentals (including sod). Therefore, all products registered for pasture as well as for use in ornamental plants can be used in sod growing.

The "Grama Legal" National Association also acted to regulate the legislation on seedlings by including the sod production chain in Law no. 10,711 / 2003, regulated by Decree No 5,153 / 2004. This decree establishes that the natural or legal person, engaged in the production, processing, repacking, storage, analysis, trade, import or export of seeds or seedlings, is required to register with the National Registry for Seeds and Seedlings - RENASEM. Acquisition of seeds and seedlings from producers not registered with RENASEM constitutes a minor offense (Associação Nacional Grama Legal, 2020).

\footnotetext{
${ }^{2}$ Scroccaro, P. L. (Farmer, Curitiba, PR, Brazil) Personal communications. 2020

${ }^{3}$ Arruda, R. L. B. (former Itograss owner, Itapetininga, SP, Brazil). Personal communication, 2020.

${ }^{4}$ ITO, M. (former Itograss owner, Itapetininga, SP, Brazil). Personal communication, 2020

${ }^{5}$ MATTE, M. L. (Director of the Green Grass, Porto Alegre, RS, Brazil). Personal communication, 2020.
} 


\section{Turf species and cultivars grown in Brazil}

Cultivated turf is considered that which is planted and receives the various cultural treatments such as fertilization, weed control, cutting, irrigation, and whose grower is registered with RENASEM (Associação Nacional Grama Legal, 2020).

Thirteen turf species are registered in the National Register of Cultivars (NRC) cultivated in Brazil (MAPA, 2020), as they are cool-season grasses, whose seeds are imported to be used in sports fields, during fall-winter. Cool-season grasses grow properly in colder climates, but cannot tolerate high temperatures. Warm-season grasses thrive very well in tropical climates, but grow little, or even cease to grow, at low temperatures (Emmons and Rossi, 2016).

Turfs can have four growth habits: rhizomatous, stoloniferous, rhizomatous and stoloniferous, and cespitose (Christians et al., 2016). In Brazil, cespitose grasses are not cultivated. Turfs with rhizomatous and stoloniferous growth in Brazil are: Zoysia japonica Steud; Zoysia matrella (L.) Merr.; Zoysia japonica Steud. $\times$ Zoysia tenuifolia Willd. ex Thiele (Zoysia pacifica); Cynodon dactylon (L.) Pers. $\times$ Cynodon transvaalensis Burtt Davy; Cynodon dactylon (L.) Pers. and Paspalum vaginatum Swarz (Christians et al., 2016; MAPA, 2020).

Zoysia japonica Steud, known as Esmeralda, is the most popular and the most widely sold cultivar in Brazil (74\% to $81 \%$ of the national market), having been registered in MAPA in 2000, despite being sold since 1983 (Zanon and Pires, 2010; MAPA, 2020). The other registered cultivars are called Japonesa, Zoysia, ITG3 and ITG5. The latter received the trade name Imperial ${ }^{\mathrm{TM}}$, in Brazil, and was registered as Empire ${ }^{\mathrm{TM}}$, in the USA, constituting the most produced Zoysia in Florida, (Patton et al, 2017), besides Mexico, Australia, and South Africa (Itograss, 2020b). This was the first protected grass cultivar on the Brazilian market, selected by agricultural engineer Roberto Gurgel (Google Patents, 2000). Emerald and Imperial grass stand out for their versatility, as they can be used in ornamental lawns and recreational, sports and functional turfs; low maintenance (good resistance to traffic and slow growth); high adaptability to different climates and soils in the regions of Brazil; and good availability throughout the country (Jeffries, et al., 2017; Patton et al, 2017; Sod Solutions, 2020a). These turfs are tolerant to half shade, salinity and drought and are harvested in sods, rolls or large rolls, at cutting heights ranging from 13 to $64 \mathrm{~mm}$ (Patton et al, 2017).

The first cultivar of Zoysia matrella (L.) Merr. was registered in Brazil in 2014, as IG 001, and gained prominence under the name of Zeon ${ }^{\mathrm{TM}}$. It was brought to the country to be used in the Olympic golf course in Rio de Janeiro, forming a denser sod, with thinner leaves than those of 'Emerald', besides that is also used in ornamental lawns (Magni et al., 2017; Greengrass, 2020a). Zoysia matrella have better shade tolerance compared to the Zoysia japonica (Wherley, et al. 2011; McCarty, 2018). This turf is harvested in sods or large rolls, at cutting heights from 6.4 to $51 \mathrm{~mm}$ (Patton et al., 2017).

Zoysia japonica Steud. $\times$ Zoysia tenuifolia Willd. ex Thiele (Zoysia pacifica) was introduced in Brazil and registered as BK-9 in 2016, receiving the trade name GeoZoysia $^{\text {TM }}$. (MAPA, 2020). The hybrid is part of the group called mini-zoysia. However, it still has small relevance in the national market. Its leaves are thinner than those of Zeon ${ }^{\mathrm{TM}}$, due to the cross with Z. pacifica (Patton et al., 2017), formerly used in Japanese gardens (very thin and pointed leaves) (Unruh et al., 2016), forming a very dense sod, but not tufts. It is characterized by fast lateral growth and recovery rate, and improved cold hardiness, compared to other Zoysia grass varieties (Google Patents, 2016). The turf is harvested in sprigs, sods or large rolls and can be used in ornamental lawns and sports turfs. It is indicated mainly for coastal areas due to its high tolerance to salinity (Itograss, 2020c). GeoZoysia ${ }^{\mathrm{TM}}$ is noted for good shade tolerance (McCarty, 2018).

Cynodon dactylon $(\mathrm{L}$.) Pers. $\times$ Cynodon transvaalensis Burtt Davy, known as bermudagrass, is a hybrid for use in sports turfs. Its most well-known cultivars are Tifway 419, registered in 2000, and ITG-6 (2007), which had received the trade name Tifway 419, despite being marketed since the 90s (Zanon and Pires, 2010; MAPA, 2020). These species have been used in soccer and golf fields (Santos and Castilho, 2018) due to their fast growth and rapid regeneration as well as good traffic tolerance, but present a low tolerance to shading. Tifdwarf (registered in 2009) and Tifeagle (registered in 2000) (MAPA, 2020) are cultivars of "dwarf" and "ultra-dwarf" bermudagrasses, respectively, which have very short and narrow leaves and tolerate cuttings heights up to $3 \mathrm{~mm}$, which allows their use in golf course greens (Baxter and Schwartz, 2018). Cultivar Latitude $36^{\mathrm{TM}}$ was registered in 2015 (MAPA, 2020), having very thin leaves, good trampling tolerance, fast regeneration and greater tolerance to low temperatures when compared with other bermudagrasses sold in Brazil, despite not yet having been released on the market (Sod Solutions, 2020b). Hybrid bermudagrasses are sold in sprigs, sods or large rolls.

The species Cynodon dactylon (L.) Pers., also known as bermudagrass, besides it is not a hybrid. The most wellknown cultivar is the Celebration ${ }^{\mathrm{TM}}$, registered in NRC as Rileys Super Sport in 2013 (MAPA, 2020). Celebration ${ }^{\mathrm{TM}}$ is one of the main turfs used in soccer stadiums, such as Maracanã, Morumbi, Mineirão, and Vila Belmiro, due to its good tolerance to partial shading and fast growth, that is superior to Tifway 419 (Dunne, et al., 2017; NTEP, 2017). In addition, this cultivar presents more attractive bluish green color (Itograss, 2020d). Another cultivar registered in Brazil, in 2014, was Barazur, (commercially known as Discovery ${ }^{\mathrm{TM}}$ ), although it is less cultivated and commercialized. The cultivar differs from other bermudagrasses, mainly due to requirement of less cutting, which also allows its use in ornamental lawns, in addition to displaying good drought tolerance and a very attractive dark green color (Google Patents, 2012; Caturegli et al., 
2014; Qually Grama, 2020). Nonetheless, if not properly maintained, spots will appear with different shades of green. Barazur is sold in sods or large rolls. Other cultivars were registered in the NRC but are not produced in Brazil, which imports them as seeds (MAPA, 2020). Common and hybrid bermudagrasses represent $1 \%$ to $2 \%$ of the national market (Zanon and Pires, 2010).

There are three cultivars of Paspalum vaginatum Swarz. registered in NRC (Seashore Paspalum ${ }^{\mathrm{TM}}$, Conquista ${ }^{\mathrm{TM}}$ and Seaspray $^{\mathrm{TM}}$; registered between 2005 and 2007), and only the first is still sold in the country (Greengrass, 2020b; MAPA, 2020). This fine-textured turf adapts very well to coastal regions thanks to its high tolerance to salinity and to sandy and infertile soils Because it tolerates low cutting heights $(2.5 \mathrm{~mm})$ and trampling, it can be used in sports turfs (Team UGA, 2020).

Cultivated grasses with stoloniferous growth in Brazil are Axonopus affinis Chase and Stenotaphrum secundatum (Walter) Kuntze (Christians et al., 2016). Axonopus affinis Chase was the first turf cultivated in Brazil - initially, in the state of Paraná, and then in São Paulo. It is the second most widely sold grass species in the country (17\% to $24 \%$ of the market) (Zanon and Pires, 2010). Known as sempre-verde, curitibana or São Carlos, it is indicated for use in ornamental lawns due to its low maintenance and good adaptation to less fertile soils. This grass has large leaves, medium density and good tolerance to partial shade and low temperatures, but does not tolerate trampling, so it is not suitable for sports turfs (Emmons and Rossi, 2016). According to Kojoroski-Silva et al. (2011) São Carlos grass belongs to the Axonopus affinis species, while the sempre-verde grass belongs to the Axonopus compressus (Sw.) P. Beauv.] species. Its most striking differences for identification purposes are prefoliation, which in the first is conduplicated and, in the second, convoluted. The São Carlos Plus ${ }^{\mathrm{TM}}$ cultivar, with broader leaves than curitibana, was recently introduced in Brazil. In production area, it provides firmer sods, which facilitates harvesting and transportation (Itograss, 2020e). The cultivars registered under the NRC are not cultivated, only sold as seeds.

Stenotaphrum secundatum (Walter) Kuntze, known as St. Augustine or English grass, has excellent adaptability to coastal regions, with broad, smooth leaves and a rounded tip (Christians et al., 2016). Two of these cultivars are registered in the NRC: Santo Agostinho and Palmetto, both in 2000 (MAPA, 2020). However, it has been marketed in Brazil, only under the name of Santo Agostinho, since the 1990s. Its use in Brazil was reduced due to the difficulty in maintaining the ideal cutting height (50 to $60 \mathrm{~mm}$ ), disease incidence, inflorescence production, which affects turf aesthetics, and low producer availability.

An example of cultivated turf with rhizomatous growth in Brazil is Paspalum notatum Flüggé, native to South America and found in fields in Brazil (Chistians et al., 2016; Souza et al, 2020). The species has received several names, such as batatais, cuiabana, forquilha, gramão, mato-grosso and bahia. There are two cultivars registered in Brazil (Bahia and Pensacola), sold as seeds (MAPA, 2020). On most situations, slabs are extracted from natural fields; however, there are a few producers who grow batatais grass as sods and that are certified by RENASEM. Since this species is native, it develops very well in tropical conditions and in low fertility soils and has high tolerance to drought but low tolerance to cold, shade and salinity (Emmons and Rossi, 2016). Batatais grass has broad leaves, exposed rhizomes and long inflorescences, which has a hard negative impact on its appearance. This species may be used in ornamental lawns and functional and sports turfs.

Four cultivars of Paspalum notatum var. latiflorum Döll (Aruaí, Maritaca, Tiriba and Tuim) and one of Axonopus parodii (Valls, ined.) (Curica) are also registered, which have been selected from the Paspalum germplasm bank of Embrapa Southeast Livestock (MAPA, 2020; Souza et al., 2020). These have been tested by growers in the production fields and should soon be available for the market, to be used mainly as functional sod, like in highways and airports.

\section{Sod production in Brazil over the years}

Until the 1990s, the major sod-producing centers were concentrated in the states of São Paulo and Paraná. Then, producers started to migrate from there to other regions of the country such as the Northeast, Rio de Janeiro and Goiás, or new ones emerged. According to Zanon and Pires (2010), this expansion was due to the economic crisis, mainly in the agricultural area, which caused several producers to enter the sector; the change in the consumer market, which became more demanding regarding the sod product; and the distance from old areas of sod production to new consumer markets. In the period from 2005 to the third quarter of 2007, there was a small growth in demand for sod in Brazil. However, from the last quarter of 2007 to the first quarter of 2009, this increase was significant. In the following months of the same year, because of the country's financial crisis, demand was lower than in the beginning of 2008. In 2010, demand remained stable throughout the year. According to the survey conducted through interviews, the estimated planted grass area was 12,421 ha of Esmeralda (74\%), 4,027 ha of São Carlos grass $(24 \%), 203$ ha of bermudagrass $(1.2 \%)$ and 139 ha of other grasses, which represented $0.8 \%$ of the total (Zanon and Pires, 2010).

According to Arigoni (2012), the number of sod producers in that year was 200 , who produced 20 varieties across the country. Pires ${ }^{10}$ estimated, through a survey with producers in 2015 , that there were approximately 22,000 ha of sod production in Brazil. The state of São Paulo alone accounted for 10,887 ha, with $75 \%$ of this area located in the municipality of Itapetininga. Based on surveys carried out by the National "Grama Legal" Association and Agrabras, Antoniolli (2015) estimated an area of 24,000 ha. 
According to estimated data, there was an increase of $43 \%$ in sod production area in Brazil, in the period from 2010 to 2015 . This increase reflecting the performance of the economy and civil construction, and the expansion in use of the bermudagrass, which was driven mainly by the high demand from sports events such as the FIFA Soccer World Cup in 2014 and the Olympic Games in 2016 in Brazil (Antoniolli, 2015).

The latest estimate of sod production in the country, a survey carried out by the "Grama Legal" National Association in 2018, indicated a small retraction in the market, which can be justified by the economic slowdown. The participation of each region in the sod production in 2018 was as follows: Southeast - 45\%, South - 24\%, Center-West - 16\%, North/Northeast - 15\%.

For 2020, the Association estimate that the production area will have reached 25,000 hectares, in Brazil, as driven by the use of sod on highways and at airports.

\section{Turfgrass marketing in Brazil}

The sod is harvested mechanically with harvest machines attached or adapted to a tractor. Depending on the operation, there are basically two types of machines most used in Brazil. A simpler harvest machine, that is coupled to the tractor's three-point hitch system, harvesting sod with dimensions of $1.25 \times 0.40 \mathrm{~m}$, which are subsequently arranged in the form of a roll; and another that is adapted on the side of the tractor, harvesting sods in the form of slabs, with dimensions of $0.625 \times 0.40 \mathrm{~m}$ (Godoy et al., 2012). The latter has a harvest system, a conveyor and a suspended platform in the rear where sods are placed manually on wooden pallets. This facilitates the transport, which is carried out with forklifts (Christians et al., 2016). Raats et al. (2012) suggest the use of $0,40 \times 0,25 \mathrm{~m}$ sods, spaced of $0,10 \mathrm{~m}$, which allowed an economy of $36,5 \%$ in the initial costs.

Another form of selling sod is in rolls (commercial names: big roll, max-roll, grand roll, large rolls, etc.). In this case, on harvesting, instead of harvesting the turf into a sod, it is rolled up in rolls with dimensions of $0.75 \mathrm{~m}$ in width and 30 to $40 \mathrm{~m}$ in length (Godoy et al., 2012). Advantages include rapid establishment of the turf; reduced cost of labor; and less time necessary for implementation and amendments between sods, which allow for a rapid use in the case of a game match (Itograss, 2020f).

Currently, large, thicker rolls of turf, $12 \mathrm{~m}$ long and $1.20 \mathrm{~m}$ wide are commercialized, which allow a ready-toplay pitch in record time, which varies from 2 to 3 days (Itograss, 2020f).

For the implantation of turfgrass in the athletic fields, where the soil is not desired, due to the sand substrate (Mateus et al., 2017), it can be used the sprigging.
Sprigging utilizes both rhizomes and stolons, called sprigs, as method of propagation. These sprigs have little to no soil associated with them. Sprigging is considered to be the most economical means of turfgrass establishment (McCarty, 2018). Sprigs are sold in boxes, which they should keep refrigerated (Emmons and Rossi, 2016).

Sod is sold through resellers (nurseries, florists, etc.) or directly by producers, which has grown, due to the price of the final product and the expansion of the producers truck fleet.

The commercial structure can vary considerably, depending mainly on the size of the company, with some owning commercial departments and departments for other services such as implementation, irrigation, maintenance, and after-sales. Other companies selling the sods directly in the production area, with the cutting and transport of the sod being at the expense of third parties.

According to Zanon and Pires (2010), especially for the sports turf sector, the product has been marketed together with the respective application technology, such as maxiroll or sprigs.

\section{Conclusions}

Like other developing countries, turfgrass areas in Brazil are, increasingly, be part of the scenery of houses, condominiums, squares, sports areas. The increase in the consumption of turfs, however, should accompany the economy.

Sod production in Brazil started in the state of Paraná, but today it is spread over almost the entire country, occupying about 25 thousand hectares, and two associations of sod growers.

In the Brazilian market, there are 13 species of turf and more than 20 cultivars available. Turfs are sold on sods, rolls, big rolls, sprigs, or "ready-to-play" sods.

\section{Acknowledgment}

The authors are thankful to the support of the Tutorial Education Program (PET). Also, we would like to thank Camila de Fátima Silva Pires, Marcelo Lara Matte, Minoru Ito, Pedro Luis Scroccaro and Rene Luiz Barreto de Arruda for the information provided.

\section{Author contribution}

RLVB: bibliographic review, data collection and elaboration of tables and text. LJGG: bibliographic review, elaboration and revision of the text. CB: contribution in the text, bibliographic and text review. AJMS: bibliographic review and formatting of the article. LSC: data collection and contribution in the text. 


\section{References}

ANTONIOLLI, D. Produção, regularização e conquistas do mercado de gramas cultivadas no Brasil. In: MATEUS, C.M.A.; VILLAS BÔAS, R.L.; ANDRADE， T.F.; OLIVEIRA, M.R.; BACKES, C.; SANTOS, A.J.M.; GODOY, L.J.G. Tópicos Atuais em Gramados IV, Botucatu: UNESP, FEPAF, 2015. p.9-22.

ARIGONI, P. Balanço do projeto Grama Legal. In: BACKES, C.; GODOY, L.J.G.; MATEUS, C.M.A.; SANTOS, A.J.M.; VILLAS BÔAS, R.L.; OLIVEIRA, M.R. Tópicos Atuais em Gramados III, Botucatu: UNESP, FEPAF, 2012. p.80-90.

ASSOCIAÇÃO NACIONAL GRAMA LEGAL. Sobre nós. 2020. Available at: <https://gramalegal.com/sobre>. Accessed Aug. 07, 2020.

BAXTER, L. L.; SCHWARTS, B. M. History of Bermudagrass turfgrass breeding research in Tifton, GA. Hortscience, v.53, n.11, p.1560-1561, 2018. DOI: https:// doi.org/10.21273/HORTSCI13257-18

BRASIL. Lei $\mathbf{n}^{0}$ 10.711, de 5 de Agosto de 2003. Institui no Mapa. Diário Oficial da União. Objetiva garantir a identidade e a qualidade do material de multiplicação e de reprodução vegetal produzido, comercializado e utilizado em todo o território nacional. DF: Presidência da República, [2003]. Available at: <http://www.planalto.gov. br/ccivil_03/LEIS/2003/L10.711.htm>. Accessed on: July $15,2020$.

BRASIL. Decreto $\mathrm{n}^{\circ}$ 5.153, de 23 de Julho de 2004. Aprova o Anexo Regulamento da Lei $\mathrm{n}^{\circ} 10.711$, de 5 de agosto 2003, que dispõe sobre o Sistema Nacional de Sementes e Mudas -SNSM. DF: Presidência da República, [2004]. Available at: <http://www.planalto.gov.br/ ccivil_03/Ato2004-2006/2004/Decreto/D5153.htm>. Accessed on: July 15, 2020.

CATUREGLI, L.; LULLI, F.; FOSCHI, L.; GUGLIELMINETTI, L.; BONARI, E.; VOLTERRANI, M. Monitoring turfgrass species and cultivars by spectral reflectance. European Journal of Horticulture Science, v.79, n.3., p.97-107, 2014. DOI: https://www.jstor.org/ stable/24126906

CHRISTIANS, N.E.; PATTON, A.J.; LAW, Q.D. Fundamentals of turfgrass management, 5ed. New York: John Wiley \& Sons, 2016. 480p.

DUNNE, J. C.; MILLER, G. L.; ARELlANO, C.; BRANDENBURG, R. L.; SCHOEMAN A.; MILLALEWIS, S. R. Shade response of bermudagrass accessions under different management practices. Urban Forestry \& Urban Greening, v.26, p.169-177, 2017. DOI: https://doi. org/10.1016/j.ufug.2017.02.011
EMMONS, R.; ROSSI, F. Turfgrass science and management, 5ed. Stanford CT: Cengage Learning, 2016, $608 \mathrm{p}$.

GODOY, L.J.G.; BACKES, C.; VILLAS BÔAS, R.L.; SANTOS, A.J.M. Nutrição, adubação e calagem para produção de gramas. Botucatu: FEPAF, 2012. 146p.

GOOGLE PATENTS. Zoysia grass plant named 'SS500', 2000. Available at: <https://patents.google.com/ patent/USPP11466P/en.> Accessed on: July 15th, 2020.

GOOGLE PATENTS. Bermuda grass plant named 'Barazur', 2012. Available at: <https://patents.google. com/patent/USPP22963P3/en> Accessed on: July 8th, 2020 .

GOOGLE PATENTS. Zoysia japonica L. $\mathbf{x}$ Zoysia tenuifolia L. plant named 'BK-9', 2016. Available at: $<$ https://patents.google.com/patent/US20150020273P1/ en. $>$ Accessed on: July 7th, 2020.

GRAMEIRAGABARDO.Empresa-Grameira Gabardo, 2020. Available at: <http://www.grameiragabardo.com.br/ empresa/>. Accessed on: Aug 5th, 2020.

GREENGRASS. Zoysia Zeon ${ }^{\mathrm{TM}}, 2020$ a. Available at: < http://www.greengrass.com.br/gramados/a/214>. Accessed on: Aug 09th, 2020.

GREENGRASS. Paspalum Seashore, 2020b. Available at: < http://www.greengrass.com.br/gramados/a/215>. Accessed on: Aug 9th, 2020.

INFOGRAMA. Grama Legal - Um projeto da Agrabras, 2015. Available at: <http://infograma.com.br/grama-legalum-projeto-da-agrabras/>. Accessed on: Aug 6th, 2020.

ITOGRASS. Empresa - História, 2020a. Available at: $<$ https://itograss.com.br/empresa/>. Accessed on: Aug 5th, 2020.

ITOGRASS. 2020b. Tipos de grama - Grama Esmeralda Imperial $^{\circledR}$. Available at: <https://itograss.com.br/gramaesmeralda-imperial/> Accessed Aug. 9, 2020.

ITOGRASS. 2020c. Tipos de grama - Grama Geo Zoysia $^{\text {TM }}$. Available at: <https://itograss.com.br/gramageo-zoysia/>. Accessed on:Aug. 5, 2020.

ITOGRASS. 2020d. Tipos de grama - Grama bermudas Celebration $^{\mathrm{TM}}$. Available at: < https://itograss.com.br/ grama-bermudas-celebration/>. Accessed on: Aug 4th, 2020.

ITOGRASS. 2020e. Tipos de grama - Grama São Carlos Plus $^{\circledR}$. Available at: < https://itograss.com.br/grama-saocarlos-plus/>. Accessed on: Aug 8th, 2020. 
ITOGRASS. 2020f. Formato - Maxi rolo. Available at: $<$ https://itograss.com.br/formatos/maxi-rolo/>. Accessed on: Aug 8th, 2020.

ITOGRASS. 2020g. Formato - Ready-to-play. Available at: $\quad$ https://itograss.com.br/formatos/ready-to-play/>. Accessed Aug. 9, 2020.

JEFFRIES, M. D.; GANNON, T. W.; YELVERTON, F. H. Zoysiagrass sod establishment along guardrails: evaluation of cultivars, soil preparation techniques, and planting timings. Crop Science, v.57, p.993-1000, 2017. DOI: https://doi.org/10.2135/cropsci2016.09.0740

KOJOROSKI-SILVA, C. M.; SCHEFFER-BASSO, S. M.; CARNEIRO, C. M.; GUARIENTI, M. Desenvolvimento morfológico das gramas Esmeralda, São Carlos e Tifton 419. Ciência e agrotecnologia, v.35, n.3 p.471477, 2011. DOI: http://dx.doi.org/10.1590/S141370542011000300005 .

McCARTY, L.B. Golf turf management. Boca Raton: Taylor \& Francis, 2018. 760p

MAGNI, S; POMPEIANO, A.; GAETANI, M., CATUREGLI, L.; GROSSI, N.; MINELLI, A.; VOLTERRANI, M. Zoysiagrass (Zoysia spp. Willd.) for European lawns: A review. Italian Journal of Agronomy, v.12, n.925, p.395-402, 2017. DOI: https://doi.org/10.4081/ ija. 2017.925

MAPA. Ministério da Agricultura, Pecuária e Abastecimento. 2020. CultivarWeb. Available at: http:// sistemas.agricultura.gov.br/snpc/cultivarweb/cultivares registradas.php. Accessed July 7, 2020.

MATEUS C. M. D’A.; OLIVEIRA, M. R.; JACON, C. P. R. P.; TAVARES, A. R.; SARTORI, M. P.; FERNANDES, D. M.; VILLAS BÔAS, R. L. Influence of substrate base on sports field covered with bermudagrass. Ornamental Horticulture, v. 23, n. 3, p.319-328, 2017. DOI: http:// dx.doi.org/10.14295/oh.v23i3.1104

NTEP - National Turfgrass Evaluation Program. 2013 National Bermudagrass Test - 2013-17 Data - Final Report NTEP No. 18-14. Available at:. <http://www.ntep. org/data/bg13/bg13_18-14f/bg13_18-14f.pdf>. Accessed July 16, 2020.

PATTON, A.J.; SCHWARTZ, B.M.; KENWORTHY, K.E. Zoysiagrass (Zoysia spp.) history, utilization, and improvement in the United States: a review. Crop Science, v.57, p.37-72, 2017. DOI: https://doi.org/10.2135/ cropsci2017.02.0074

QUALLY GRAMA. 2020. Grama Discovery ${ }^{\mathrm{TM}}$ : aplicações e características da Grama Discovery ${ }^{\mathrm{TM}}$. Available at: $<\quad$ http://www.quallygrama.com.br/grama-discovery $>$ Accessed on: August 8, 2020.
RAATS, L. E. S.; PAIVA, P. D. O.; RIBEIRO, M. N. O. Avaliação comparativa de formatos de placas e plugs para plantio de grama esmeralda. Ornamental Horticulture, v.18, n.2, p.115-120, 2012. DOI: https://doi.org/10.14295/ rbho.v18i2.400.

SANTOS, P. L. F.; CASTILHO, R. M. M. Substrates in the development of a sports turfgrass "Tifton 419". Ornamental Horticulture, v.24, n.2, p.138-144, 2018. DOI: https://doi.org/10.14295/oh.v24i2.1055

SCHVABE, H. Família Gabardo do Umbará. Gazeta do Bairro. Curitiba, novembro, 2011. Caderno C - Edição 234. p.15.

SOD SOLUTIONS. 2020a. Sod university - Empire Turf Zoysia: Breeder Profile. Available at: < https:// sodsolutions.com/industry/empire-turf-zoysiagrassbreeder-profile/>. Accessed on: Aug 5th, 2020.

SOD SOLUTIONS. 2020b. Latitude $\mathbf{3 6}^{\text {TM }}$ bermudagrass - everything you need for a latitude lawn. Available at: < https://sodsolutions.com/grasses/latitude36bermudagrass/>. Accessed Aug. 6, 2020.

SOUZA, F.H.D.; GUSMÃO, M.R.; CAVALLARI, M.M.; BARIONI Jr, W. Characterization of the potential of native grasses for use as lawns. Ornamental Horticulture, v.26, n.1, p.109-120, 2020. DOI: https://dx.doi. org/10.1590/2447-536x.v26i1.2067

TEAM UGA. 2020. Seashore Paspalum: The Team UGA Advantage - University of Georgia. Available at: $<$ https:// gapaspalum.com/>. Accessed on: July 7th, 2020.

UNRUH, J. B.; TRENHOLM, L. E.; CISAR, J. L. Zoysiagrass for Florida Lawns - Environmental Horticulture Department, UF/IFAS Extension. Available at: $\quad<$ https://edis.ifas.ufl.edu/pdffiles/LH/LH01100.pdf $>$. Accessed on: July 18th, 2020.

WHERLEY, B. G.; SKULKAEW, P.; CHANDRA, A.; GENOVESI, A. D.; ENGELKE, M. C. Low-input performance of zoysiagrass (Zoysias spp.) cultivars maintained under dense tree shade. HortScience, v.46, n.7, p.1033-1037. DOI: https://doi.org/10.21273/ HORTSCI.46.7.1033

ZANON, M.E.; PIRES, E.C. Situação atual e perspectivas do mercado de grama no Brasil. In: GODOY, L.J.G.; MATEUS, C.M.D'A.; BACKES, C.; VILLAS BÔAS, R.L. Tópicos atuais em gramados II, Botucatu: UNESP, FEPAF, 2010. p.47-53. 